Florida A\&M University College of Law Scholarly Commons@ FAMU Law

Library Faculty Publications

Law Library

$2-2018$

\title{
Can They Do That?: The Limits of Governmental Power Over Medical Treatment
}

Paul Jerome McLaughlin Jr.

Florida AぬM University College of Law, paul.mclaughlin@famu.edu

Follow this and additional works at: https://commons.law.famu.edu/library-facpub

Part of the Constitutional Law Commons, Fourteenth Amendment Commons, and the Health Law and Policy Commons

\section{Recommended Citation}

Paul Jerome McLaughlin Jr. (2017) Can They Do That?: The Limits of Governmental Power over Medical Treatment, Journal of Legal Medicine, 37:3-4, 371-388, DOI: 10.1080/01947648.2017.1385039

This Article is brought to you for free and open access by the Law Library at Scholarly Commons @ FAMU Law. It has been accepted for inclusion in Library Faculty Publications by an authorized administrator of Scholarly Commons @ FAMU Law. For more information, please contact paul.mclaughlin@famu.edu. 


\section{This is an original manuscript / preprint of an article published by Taylor \& Francis in the Journal of Legal Medicine on Feb. 23, 2018, available online: http://www.tandfonline.com/10.1080/01947648.2017.1385039.}

\section{Can They Do That?: The Limits of Governmental Power over Medical Treatment}

Paul Jerome McLaughlin Jr.

1. Introduction

With the increase in popularity of television shows such as Bones, Crossing Jordan, Law and Order, and NCIS the interactions between law and medicine have become topics of popular interest. ${ }^{1}$ Cases involving abortion, artificial insemination, the right to die, and other health and legal issues are commonly discussed on national news broadcasts and talk show programs, which have increased awareness of how developments in law and medicine can affect patients and society. ${ }^{2}$ Debates over making vaccinations for school aged children mandatory, ${ }^{3}$ minor's rights to undergo chemotherapy, ${ }^{4}$ judicially enforced parenting plans involving non-therapeutic procedures on minors, ${ }^{5}$ and attempts to place nurses in quarantine have gained national and international attention and raised questions as to the limits of the government's power to compel medical treatment. ${ }^{6}$ This article provides an overview of the government's policing powers over the public's or an individual's medical care and examines when government agents are acting from the strongest positions of authority when exercising their power to ensure health and safety.

\subsection{Governmental Powers Over Public Health Concerns}

\subsubsection{Enforcement of Quarantines}

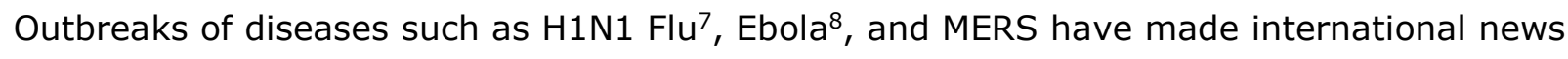
and caused government health officials around the world to quarantine individuals who showed symptoms of disease along with others who were asymptomatic but were suspected of unknowingly carrying the same pathogens. ${ }^{9}$ While quarantine can be unwieldy to implement due to its inherent ethical, legal, and practical concerns, it has been used to prevent the spread of diseases throughout history. ${ }^{10}$ Under the powers to ensure public welfare granted by Article 1 of the Constitution ${ }^{11}$ and the Commerce Clause $^{12}$, governmental agents have the authority to quarantine those that they believe carry infectious diseases despite such an action infringing on 
an individual's rights to freedom of moment and self-determination. ${ }^{13}$ Under the United States Code, Federal agents have the power to detain, examine, and isolate those that they believe are carrying transmittable diseases that could pose a public health risk. ${ }^{14}$ When faced with possible health threats due to infectious disease, states and their health care agencies have the task of controlling disease outbreaks within their borders by implementing quarantines that follow the statutory guidelines that their legislatures create. ${ }^{15}$

Government agents have broad discretion when determining whether an individual should be placed in quarantine or not, but determinations as to quarantines must be based on facts that substantiate a reasonable belief that the individual may be carrying a communicable disease. ${ }^{16}$ An individual held under quarantine has the right to challenge their detention using a writ of habeas corpus. ${ }^{17}$ The general rule of law is that if an individual is put in quarantine under a reasonable suspicion of them carrying a disease that proves to be incorrect the individual cannot recover damages due to the sovereign immunity granted to a governmental actor in carrying out an action aimed to safeguard the public health. ${ }^{18}$ However, if it is shown that a governmental agent or agency acted negligently in detaining the individual, damages stemming from the wrongful detention can be awarded. ${ }^{19}$ After the Ebola outbreak in 2014, several health experts and aid workers were placed under quarantine with little or no official explanation as to why they were being quarantined, how they could contest the quarantine, or how to obtain food and receive needed services. ${ }^{20}$ Of the health care professionals who were put into quarantine, only one sued for damages for being placed into quarantine improperly. ${ }^{21}$ After being placed in a quarantine that did not follow official protocols and having her identify publicized, Kaci Hickox, a nurse who returned to the states after showing no symptoms and testing negative for infection, sued the acting governor of New Jersey and several state officials for damages for invasion of privacy, false imprisonment, and violating her due process rights. ${ }^{22}$

Beyond having the power to quarantine human patients, government officials have the authority to quarantine animals and plants that could carry diseases harmful to humans or that could adversely affect interstate commerce. ${ }^{23}$ If necessary to prevent the spread of disease, or prevent illness from contaminated food, animals and plants can be ordered destroyed by 
governmental agents. ${ }^{24}$ While government agents' ability to destroy disease carrying animals and plants is universal, the ability of owners to recover some or fair market value for the animals or plants lost varies depending on the laws governing the agents involved and the jurisdictions where the destruction occurred..$^{25}$

\subsubsection{Compelling Vaccinations}

In reaction to an outbreak of measles, ${ }^{26}$ the California Senate passed a new set of vaccination laws to eliminate exemptions for children whose parents do not agree with vaccinations due to religious or philosophical beliefs. ${ }^{27}$ The passage of the new vaccination laws became a national media story, and drew comments, both positive and critical, from celebrities such as the comedian John Carrey. ${ }^{28}$ The issue of whether the law should require school-aged children to be vaccinated garnered enough popular attention that it was included political debates leading up to the 2016 presidential elections. ${ }^{29}$ Medical experts and vaccine supporters have argued that lower rates of vaccination in California aided the spread of the measles outbreak, ${ }^{30}$ and has increased the risk of the spread of disease overall. ${ }^{31}$ Some California parents have resisted mandatory vaccinations as an infringement on their rights and citing health concerns for their children. ${ }^{32}$ The parents argue that the possible adverse reactions to vaccines are more harmful than the diseases that they are meant to prevent, infringe on their right to raise their children without interference, and that there is little chance of an outbreak of the diseases that vaccines are designed to prevent in the state's school systems. ${ }^{33}$

The legal and social debate as to when government actors can mandate vaccinations has been ongoing for over a century. ${ }^{34}$ In Jacobson $v$. Massachusetts, a ruling dating back to 1905 , the Supreme Court held that mandating vaccinations one of the policing powers granted to the government by the Constitution. ${ }^{35}$ The court stated that while there might be a factual basis as to the dangers of vaccines it would not examine such issues since the legislatures that had passed vaccination laws had done so before passing their legislation and the court was not willing to act in a way that would unnecessarily limit how states could control public health. ${ }^{36}$ The court further held that the legislatures were acting within their power to mandate vaccinations, even over an individual's protest, since concerns of public health outweighed an individual's rights to refuse 
vaccination. ${ }^{37}$ The Supreme Court has stated that the government has the power to compel children to be vaccinated before they enroll in school as a public health measure. ${ }^{38}$ Vaccinations can be required at both the primary and university levels as university boards of governors are considered government agents and have been held to have the power to require students receive vaccinations before attending classes. ${ }^{39}$ Even if a parent has religious objections to vaccinations, the Supreme Court has held that parents having religious beliefs does not grant them the right to expose others to the possibility of catching a harmful disease by refusing to have their children vaccinated. ${ }^{40}$ Courts have also held that not having a child vaccinated so that they can attend school can be considered a form of neglect, and that parents who refuse to have their children vaccinated can have their children placed in the care of a guardian and forcefully vaccinated. ${ }^{41}$

While the Supreme Court has held that mandating vaccinations is constitutional, it is the responsibility of individual states to pass and enforce vaccination laws. ${ }^{42}$ The lack of a uniform set

of laws has caused a variety of approaches to required vaccinations and vaccination exemptions. ${ }^{43}$ Some states allow parents to exempt their children from vaccinations on religious grounds, ${ }^{44}$ while others hold that all students must be vaccinated before they enter into school no matter the nature of the objections raised. ${ }^{45}$ Among the states that allow religious exemptions, a state may allow for inquiries as to the validity of a parent's religious claims before granting an exemption for a child from vaccination, ${ }^{46}$ while others consider a parent's profession of belief to be genuine without further inquiry. ${ }^{47}$ Though it has not created mandatory vaccination laws, in order to increase vaccination rates, Congress passed the National Childhood Vaccine Injury Act ${ }^{48}$ which established the National Vaccination Program and provides funds to parents of children whose children who suffer adverse reactions to vaccinations to pay for medical expenses. ${ }^{49}$

\subsection{Governmental Ability to Influence the Medical Care of an Individual}

\subsubsection{Informed Consent to Treatment}

Informed consent requires that before medical treatment can be administered by a physician a patient must be give their consent to undergo treatment. ${ }^{50}$ The doctrine of informed consent was developed to help prevent patients from undergoing medical treatment that was not in their best interests but would be lucrative for a physician to perform. ${ }^{51}$ For a patient's consent 
to be proper, a patient must be given information on the nature of a treatment, why the treatment is necessary, and told of any foreseeable risks that the treatment would involve. ${ }^{52} \mathrm{~A}$ patient's consent must also be given without emotional or physical coercion for it to be valid. ${ }^{53}$ If a physician performs a procedure without providing a patient the appropriate amount of information and gaining the patient's consent, they can be held liable for damages under tort law. ${ }^{54}$ Informed consent became a topic of legal and scholarly debate in the 1960's due to the uncertainty about what ethical and legal theories would govern its use. ${ }^{55}$ While the doctrine of informed consent has become widely accepted, there is a divergence of opinion by both legal and medical experts as to whether it should follow a professional medical standard or a standard of information needed for a patient to make a determination to accept or reject treatment. ${ }^{56}$

Informed consent arguments have been raised in regards to quarantines and vaccinations, but the courts have held that the rights of an individual to refuse treatment cannot override the need for society as a whole to be protected against the spread of disease. ${ }^{57}$ Informed consent considerations become much more prominent when governmental actors intervene in an individual's medical care decisions that cannot affect the health of others. ${ }^{58}$ When an individual is unable to consent to medical care due to emergency, impairment, or disability, treatment is often administered to safeguard their health and allow determinations as to whether further treatment would be proper or not after the period of danger or incapacity has passed. ${ }^{59}$ When an individual cannot articulate their consent and treatment is given to save their life or prevent further harm, even if the individual later argues that they would not have consented, the provider of the treatment is typically shielded from claims for damages under the emergency privilege. ${ }^{60}$ When an individual is unable or has questionable ability to consent to medical treatment due to age, mental disability, or non-permanent impairment that renders them unable to speak for themselves, proxy decision makers are given the authority to consent to or decline treatment in their stead. ${ }^{61}$

\subsubsection{Compelled Treatment of Adults}

The debate as to whether the government can order medical treatment over the objections of an individual has not been settled. ${ }^{62}$ In circumstances where a ward of the state refuses treatment that would arguably serve their long-term health, such as cases of drug addiction or 
treatable mental illness, ${ }^{63}$ government agents can order individuals to undergo treatment due to their diminished ability to make medical decisions for themselves. ${ }^{64}$ However, when an adult is not under the direct care of the government and has the full capability to make health care decisions, the question of whether government agents can force them to undergo medical treatment becomes more complex. ${ }^{65}$

A competent adult can refuse medical care over objections by governmental agents and physicians. ${ }^{66}$ The Supreme Court has held that under the Due Process Clause ${ }^{67}$ an individual has the right to refuse treatment, even if the treatment would be life saving. ${ }^{68} \mathrm{~A}$ variety of reasons have been given by patients for their refusal of treatment including religious beliefs ${ }^{69}$ and the wish to control what procedures are used to sustain their lives if they are ever in a position where they cannot speak for themselves. ${ }^{70}$

In rare circumstances, courts have ordered that life saving treatments be administered over the objections of an adult. ${ }^{71}$ In the cases that government agents have been authorized to force individuals to undergo treatment, only two scenarios have allowed for such a course of action. ${ }^{72}$ The first scenario occurs when a patient's previous objections are recorded, but an onset of physical incapacity and changes in their diagnosis calls into doubt whether the patient would continue to object to treatment. ${ }^{73}$ In Application of the President and Directors of Georgetown College, a case involving a patient who could not respond due to blood loss, the court held that doctors could proceed with a blood transfusion over the patient's previous objections due to changes in her medical diagnosis. ${ }^{74}$ The court stated that the transfusion was necessary to allow the patient the opportunity to voice her opinion as to the new information about her condition and to honor the oaths of the physicians who were charged with her care to preserve life to the best of their abilities. ${ }^{75}$ The second scenario that has allowed government agents to force medical treatment on an adult is when the patient's refusal would adversely affect minor or unborn children. ${ }^{76}$ In an illustrative case, Raleigh Fitkin-Paul Memorial Hospital v. Anderson, a patient suffering from hemorrhaging refused blood transfusions due to her religious beliefs, which put both her and her unborn child's life at risk. ${ }^{77}$ The court held that blood transfusions could be administered against the patient's will in order to preserve the life of her child, who the court held 
was due the protection of the law even without having been born. ${ }^{78}$

\subsubsection{Government Oversight of the Medical Treatment of Children}

\subsubsection{Parental Powers Over a Child's Medical Care}

Under Roman law, children were considered the property of their father who could kill, mutilate, or sell a child without legal ramifications. ${ }^{79}$ In contrast with the Roman law's approach to children's rights, the Supreme Court has held that children facing deprivation of liberty or property hold the same rights and protections under the Constitution as all other citizens. ${ }^{80}$ While parents no longer hold the power of life and death over their children, they maintain a great degree of control over their children's lives. ${ }^{81}$ Under the Constitution, parents have the right to control what medical treatments that a child receives and have the ability to refuse offered treatment for their children. ${ }^{82}$ Parents' ability to refuse treatment also includes the ability to decide to withhold treatment if it would only prolong a child's life. ${ }^{83}$

If a child faces imminent harm, government agents can compel medical treatment without parental or judicial authorization. ${ }^{84}$ The Supreme Court has held, "Parents may be free to become martyrs themselves. But it does not follow they are free, in identical circumstances, to make martyrs of their children before they have reached the age of full and legal discretion when can make that choice for themselves. 85 The current state of the law is that the parent-child relationship is a fiduciary relationship that the state has the power to govern, which includes the ability for state agents to remove a child from parental custody and place them with a guardian. ${ }^{86}$ Under the powers of parens patriae, state officials can remove a child from parental care if the refusal of medical treatment is found to amount to neglect, even if the child's parents cite philosophical or religious reasons for the refusal. ${ }^{87}$ To remove a child from parental care the state must go beyond the best interest of the child standard and show the child will suffer a severe detriment or will be under threat of physical harm if not placed with a guardian who will allow treatment. ${ }^{88}$ In Mitchel v. Davis, the court examined such a situation and placed a child under a 
government agent's care after the child's mother refused to allow the child to have corrective surgery to correct a non-life threatening, degenerative condition due to polio. ${ }^{89}$ The court held that the mother's refusal of the treatment amounted to neglect of the child due to the permanent injury it would have caused and ordered the child to undergo corrective surgery. ${ }^{90}$

The state's power to intervene on a child's behalf to ensure their health also allows state agents to make determinations as to what kinds of treatment are proper for a child for their mental and physical health. ${ }^{91}$ The government has the power to regulate mainstream treatments as well as alternative and complementary treatments that a child may receive. ${ }^{92}$ States have sought to legally punish parents who rely on spiritual or faith healing over conventional medicine, particularly when a child's life or long-term wellbeing is at risk. ${ }^{93}$ If a treatment falls outside of accepted medical norms, the state can intervene to ensure that a child gets effective treatment for their condition. ${ }^{94}$

\subsubsection{A Child's Ability to Make Medical Decisions}

In the past, children were held to be incapable of giving informed consent to medical treatments and that a child's parents had to consent to any treatment. ${ }^{95}$ If a doctor performed treatment without the consent of the child's parents, the doctor could be held liable for tort damages. ${ }^{96}$ In certain situations, minors do not have to have parental approval to undergo treatment. ${ }^{97} \mathrm{~A}$ child does not have to gain parental consent to receive treatment for venereal diseases ${ }^{98}$ or treatment regarding pregnancy. ${ }^{99}$ If a child has been emancipated by the courts, through marriage, or by living alone and being self-sufficient the child does not have to seek parental approval for medical treatment. ${ }^{100}$ The use of strict age ranges to determine whether a child can make informed decisions regarding medical treatment is discouraged due to the range of cognitive abilities of adolescents, and it has been recommended that courts make determinations as to a child's competence on an individualized basis. ${ }^{101}$ The current view regarding a child's decision-making ability is that a child can make medical decisions if the child shows an ability to understand the information provided and if the child has the appropriate level of maturity. ${ }^{102}$

The Connecticut Supreme Court discussed the criteria used to determine whether a child can be considered mature enough to make medical decisions when it determined In Re Cassandra 
C. ${ }^{103}$ Cassandra, a minor approaching the age of majority, refused treatment for leukemia after being placed under the care of a state appointed guardian due to her mother's delaying of her treatment to the extent it endangered Cassandra's life. ${ }^{104}$ Cassandra believed that the treatment would be traumatic, would extend her fight with the disease rather than cure her, and did not want to endure the side effects of the chemotherapy. ${ }^{105}$ After discussing her condition and treatment options with her doctor, Cassandra agreed to undergo therapy so long as she could remain at home. ${ }^{106}$ After receiving two treatments, bruising appeared around the treatment area and Cassandra's doctor determined that surgically inserting a "port-a-cath" would be the best way to continue treatments. ${ }^{107}$ The next day, when a state health employee went to pick up Cassandra so she could undergo the procedure to insert the port-a-cath and her treatment, Cassandra could not be located. ${ }^{108}$ Cassandra returned home after several days and refused to undergo further treatment, stating that she did not trust the doctors that were providing her care, she did not feel sick, and that she would be eighteen soon so she could not be forced to undergo further treatment. ${ }^{109}$ The commissioner of the Department of Children and Families filed for a rehearing regarding Cassandra's behavior and to determine what steps could be taken to insure that Cassandra continued her treatments. ${ }^{110}$ The lower court held that due to Cassandra's behavior, her mother's viewpoints on Cassandra's diagnosis, and the threat of the cancer becoming markedly worse, that the state could take physical custody of Cassandra and force her to undergo treatment. ${ }^{111}$ The issue of whether a minor could be considered a mature minor had not been addressed by the Connecticut Supreme court previously. ${ }^{112}$ The court held that it would follow the common law assumption that a minor is incompetent to make medical decision until the child showed the ability to make reasoned decisions and act independently. ${ }^{113}$ The court stated that a minor's conduct, ability to act and live independently from parental aid, ability to reason in a mature manner, and understanding of the situation were the factors it would take into consideration in determining whether Cassandra could be declared a mature minor. ${ }^{114}$ The court held that Cassandra's dependence on her mother, her behavior, and lack of honesty with the lower court and health care providers showed that she lacked the level of maturity needed to meet the mature minor standard and upheld the lower court's holding that Cassandra could be 
removed from her mother's custody and forced to undergo treatments. ${ }^{115}$

\subsubsection{Governmental Control Over Non-Therapeutic Treatments}

\subsubsection{Oversight of Medical Research}

\subsubsection{Protecting Prisoners and Wards of the State}

Whether due to civil or criminal commitment, state agents can compel individuals to undergo treatment for a variety of health concerns. ${ }^{116}$ However, research and medical ethics require that vulnerable populations, such as prisoners and wards of the state, be protected from exploitation and harm from medical research. ${ }^{117}$ Due to a series of abuses by governmental and corporate organizations of prisoners involved in medical studies from the 1950's to the 1970's, regulations controlling medical research using human subjects, later named the Common Rule, 118 were created to ensure that individuals were protected from mistreatment at the hands of medical researchers. ${ }^{119}$ The regulations require that review boards examine proposed research to ensure that the practices employed are ethical, safe for subjects, cost effective, and meet risk versus benefit guidelines. ${ }^{120}$ Gaining informed and uncoerced consent for participation in research treatments is an imperative ethical consideration due to participation in medical research being a voluntary act rather than a duty or necessity. ${ }^{121}$ While prison populations have been growing and there is an increasing need to study the mental and physical health factors that impact incarcerated individuals, there is reluctance on the part of researchers to use prisoners in studies due to the inherent ethical and legal considerations of using a sample group under the control and influence of prison authorities. ${ }^{122}$ Experts have recommended changes be made to the regulations controlling medical research involving prisoners to allow researchers more opportunity to look into the factors contributing to the growing prison population. ${ }^{123}$ Studies have found that prisoners and wards of the state are not unduly influenced by being under governmental guardianship ${ }^{124}$ and that their consent to participate in medical research should not be automatically viewed with suspicions of coercion. ${ }^{125}$

\subsubsection{Government Oversight of Parents Involving Children in Medical Research}

Children are among the most vulnerable groups that need protection from exploitation by guardians and medical researchers for economic gain. ${ }^{126}$ Parents' ability to consent to non- 
beneficial treatment for their children has not been defined under the law and has only been examined in two contexts. ${ }^{127}$ It has been held that parents can consent to a kidney transplant from one child to another in order to save the life of a child and if the sibling is the best candidate for donation. ${ }^{128}$ Parents can also consent to their children taking part in medical trials whether or not they are beneficial to the child, ${ }^{129}$ so long as the trials adhere to Federal research guidelines. ${ }^{130}$ The Code of Federal Regulations holds that medical trials should not expose subjects to greater than minimum risk to harm and discomfort than they would face every day. ${ }^{131}$ Processes such as blood draws and having $\mathrm{x}$ rays in medical care and research can cause pain and discomfort for children, but are treated by legal and medical experts as minor considerations when compared to the net benefits of health treatment. ${ }^{132}$

In Grimes v. Kenny Krieger, a case concerning adverse effects to children who participated in a lead paint abatement health and cost efficiency study, the Maryland Supreme Court extended protection for children participating in medical research so that if the research being conducted did not involve therapeutic treatments or provide a benefit for the children involved it would not be allowed. ${ }^{133}$ The court stressed that therapeutic research procedures offered the possibility of benefits to a child while non-therapeutic research and treatments were for the benefit of others that could be motivated to place a child in a dangerous position for personal gain and deserved stricter ethical and legal scrutiny. ${ }^{134}$ The court held that parents' or other guardians' consent could not be substituted for the consent of a healthy child to undergo non-therapeutic research when there was a possibility of harm to the child's health. ${ }^{135}$

\subsubsection{Judicial Enforcement of Parental Agreements to Non-Therapeutic Procedures on Children}

Government agents can enforce parental agreements between parents that authorize nontherapeutic procedures on a minor child. ${ }^{136}$ The case of Hironimus $v$. Nebus, garnered national attention and caused debates as to the balance of decision-making powers between children, government agents, and parents over non-therapeutic medical treatment of minors. ${ }^{137}$ In Hironimus, after learning more about the procedure, the mother of an infant child filed a motion to keep her child from being circumcised as part of a parenting plan that she signed with the child's father. ${ }^{138}$ The child's father argued that the circumcision should be allowed, but provided no 
religious grounds for seeking the circumcision of the child. ${ }^{139}$ The judge presiding over the case stated that the decision was one that parents should determine themselves and that medical testimony would weigh heavily as to what the court would hold. ${ }^{140}$ During the trial, the only medical testimony given was by Dr. Charles Flack who stated that the circumcision of the child was not medically necessary, had risks involved with the procedure, the child was outside the normal age range for a circumcision, and that he recommended that the procedure not be done. ${ }^{141}$ Without considering evidence as to the psychological impact of the procedure on the child and his relationship with his parents, ${ }^{142}$ the judge held in favor of the father and stated that the child's mother and father should behave in a manner that would be not interfere with their relationship with their child. ${ }^{143}$ Against the wishes of the court, the child's mother refused to sign the consent form and entered into a domestic abuse protection program to keep the child from his father and to keep the procedure from occurring. ${ }^{144}$ The mother was later taken into custody and imprisoned for contempt of court until she signed the consent for the circumcision. ${ }^{145}$ Children's rights groups denounced the holding, stating that it focused on the father's wishes over the child's wellbeing, violated the principles of informed consent, and that the procedure was not recommended under the Center for Disease Control recently reformed guidelines on circumcision. ${ }^{146}$

\subsection{Conclusion}

The primary goal whenever government agents intercede in medical treatment is to ensure that the public health is maintained and to protect the rights and well-being of individual citizens. Due to its mandate to provide for the common health of the nation, the government's ability to influence an individual's medical care is strongest when the possible ill effects to an individual are minor and the potential benefits to society as a whole are substantial. Medical treatments like vaccinations have been held to fall into this category, since the need to protect the public from outbreaks of potentially cripplingly or lethal diseases outweigh the short-term discomfort of receiving the vaccination and the low chance of detrimental side effects for an individual.

When government agents intervene with the medical decisions of an individual that can only affect that individual's wellbeing, the legal considerations require a more nuanced analysis 
than when weighing the rights of an individual against the general population. Government actors must balance the rights of the individual to anatomical and religious freedom against the rights of the nation as a whole to ensure the wellbeing of the population. While the common law favors an individual making medical determinations for themselves, if there is doubt as to an individual's wishes or if their decision would have an adverse impact on children and close family members, the government can intervene to ensure that the best possible outcome for all involved in the situation is given its best chance to succeed.

When intervening in medical decisions concerning minors, government agents must take into not only the parents' wishes, but the best interests of the child as well. Acting in the best interests of a child can require government agents to remove the child from parental custody and placing the child with an appointed guardian so that the child can receive treatment. Most minors cannot make medical decisions on their own, under the law. However, government agents have the duty to determine if the minor has the capacity to make informed medical decisions and allow the child to have input into their treatment if it is determined that the child is mature enough to understand the situation and the treatments they might undergo.

If medical treatment is connected with medical research, it is the government's duty to protect those who participate in the research. At risk segments of the population, such as prisoners and children, require that government agents carefully monitor the goals of the research, the methods used, and the impacts that the research has on the participants. Prisoners, due to abuses occurring in the past, are given special protection under the law to ensure that they are not taken advantage of due to their being under the control of prison officials. Children have been given more protection against potential harm from non-therapeutic research under state law than Federal law, but they are still at risk due to their being under the power of their parents and other guardians who may not always have the children's best interest in mind when they consent to the child participating in medical research.

Government agents can enforce parental agreements that require a child to undergo nontherapeutic treatments. However, when enforcing such agreements, the agents must be cognizant that non-therapeutic treatments carry a much higher standard of scrutiny than therapeutic 
treatments due to the lack of necessity for the child's health. Government agents must keep the best interests of the child at the forefront of their consideration and examine both the physical and mental impacts on the child as well as the possible ramifications of undergoing non-medically necessary procedures could have on the child's future relationship with the child's parents.

${ }^{1}$ Elisabeth A. Cawthon, Medicine On Trial 3-9 (2004).

${ }^{2}$ Id. at $134-168$.

${ }^{3}$ Rosanna Xia \& Rong-Gong Lin, Perfect Storm for Measles Outbreak; Crowed Theme Park, Holiday Travel Mix, L.A. TIMES, January 14, 2015, at A1.

${ }^{4}$ Josh Kovner, Teen Must Get Chemo at Hospital; Judge Also Denies Visits from Mother, HARTFORD COURANT, April 2, 2015, at A1.

${ }^{5}$ Associated Press, Circumcision for Florida 4-year-old Divides Parents, Spurs Lengthy Legal Battle and Draws Protests, N.Y. DAILY News, January 20, 2015, http://www.nydailynews.com/news/national/circumcision-fla-4-year-old-divides-parents-article1.2084781.

${ }^{6}$ Philip Sherwell \& David Millward, American Ebola Nurse Wins Court Battle to Avoid Quarantine Order, TeLEgRAPH, Oct. 31, 2014, http://www.telegraph.co.uk/news/worldnews/ebola/11202797/American-Ebola-nurse-wins-courtbattle-to-avoid-quarantine-order.html.

7 Influenza a H1N1 Outbreak Confirmed in Central Vietnam, Tuoi TRE News (Vietnam), Mar. 22, 2015, http://tuoitrenews.vn/society/26925/influenza-a-h1n1-outbreak-confirmed-in-centralvietnam.

8 Mark Berman, N.Y. Doctor Who Had Ebola Leaves Hospital, WASHINGTON Post, November 12, 2014 , at A2.

${ }^{9}$ Choe Sang-Hun, South Korea Quarantines Entire Village Over MERS, NEW YORK TIMES, June 11, 2015, at A4.

${ }^{10}$ Lawrence Gostin et al., Quarantine: Voluntary or Not?, 32 J. L. MED. \& ETHICS, 83, 83-86 (2004). 11 U.S. CONST. art I. 
12 U.S. CONST. art I, § 8, cl. 3.

${ }^{13}$ Gregory Campbell, Global H1N1 Pandemic, The Legal Power to Quarantine and the Conflict with Due Process Rights, 12 SAN DIEGo INT'L L. J., 497, 504-505.

${ }^{14}$ Sanitation and Quarantine 42 U.S.C. §§ 88-114 (2012).

${ }^{15}$ R.E.B., Annotation, General Delegation of Power to Guard Against Spread of Contagious

Disease, 8 A.L.R. 836, 836-843 (1920).

${ }^{16}$ People ex rel. Barmore v. Robertson, 302 Ill. 422, 432-433 (1922).

${ }^{17}$ Ex Parte Hardcastle, 208 S.W. 531, 532 (Texas Crim. App. 1919).

${ }^{18}$ Bates v. City of Houston, 37 S.W. 383, 383-384 (Texas Civ. App. 1896).

19 J.H.B., Liability of Municipality for Arrest and Detention of Person upon False Pretense that He or She is Afflicted with a Contagious Disease, 12 A.R.L. 249 (1921); Tormey v. New York (1878) 12 Hun (N.Y.) 542, 544-549 (holding that municipal agents and the cities that employ them can be held liable for damages for the wrongful quarantine of an individual if the agents if the agents acted under false pretences and personally gained from the wrongful detention).

${ }^{20}$ Sheri Fink, Debate on Quarantine Persists as Ebola Outbreak Subsides, N.Y. TIMES, Dec. 3, 2014 at $\mathrm{A} 1$.

${ }^{21} I d$.

22 M. Alex Johnson, Kaci Hickox, Maine Nurse Quarantined in Ebola Scare, Sues New Jersey Gov. Chris Christie, NBC NEws, Oct. 22, 2015, http://www.nbcnews.com/storyline/ebola-virusoutbreak/kaci-hickox-maine-nurse-quarantined-ebola-scare-sues-new-jersey-n449491. ${ }^{23}$ Mitz v. Baldwin, 289 U.S. 346, 348-352 (1933).

${ }^{24}$ Lawton v. Steele, 152 U.S. 133, 136-138 (1984).

25 J.T.W., Annotation, Right to and Measure of Compensation for Animals or Trees Destroyed to Prevent Spread of Disease or Infection, 67 A.L.R. 208, 208-216 (1930).

26 Patrick McGreevy, Senate Passes Vaccination Bill; Legislation Would Not Allow Parents to Opt Out Due to Personal Beliefs. It now goes to the Assembly, Los ANGELES TIMES, May 15, 2015, at B4. 27 S.B. 277, 2015-2016 Leg., Reg. Sess. (Ca. 2015).

28 Phil Willon, The State: A Push for Referendum on Vaccines; Ex-Lawmaker Tim Donnelly Wants 
the New Vaccination Law Overturned by Voters, Los ANGeles Times, July 2, 2015, at B4.

${ }^{29}$ Sabrina Tavernise \& Catherine Saint Louis, Vaccine Issue Arises at Republican Debate, to Doctors' Dismay, N.Y. TIMES, Sep. 18, 2015, at A20.

30 See Xia \& Lin, note 3 supra.

${ }^{31}$ E. J. Gangarosa et. al., Impact of Anti-Vaccine Movements on Pertussis: The Untold Story, 351 LANCET 356, 356-361 (1998).

32 Anakarian De La Torre-Fennell, Chapter 821: Mandated Vaccinations Bring Informed Consent, 44 McGorge L. ReV. 719, 719-720 (2013).

${ }^{33} I d$.

${ }^{34}$ Marjorie Shields, Annotation, Power of Court or Other Public Agency to Order Vaccination Over Parental Objection, 94 A.L.R. 5 $5^{\text {th }} 613,620-641$ (2001).

35 Jacobson v. Massachusetts, 197 U.S. 11, 38-39 (1905).

${ }^{36}$ Id. at $36-37$.

37 Id. at 31-35.

${ }^{38}$ Zucht v. King, 260 U.S. 174, 176 (1922).

39 Williams v. Wheeler, 138 P. 937, 939-941 (1913).

40 Prince v. Massachusetts, 321 U.S. 158, 166-167 (1944).

${ }^{41}$ Mannis v. State ex rel. DeWitt School Dist. No. 1, 398 S.W. 2d 206, 206-207 (Ark. 1965).

42 See Shields, note 34 supra.

${ }^{43} I d$.

${ }^{44}$ Department of Health v. Curry, 722 So. 2d 874, 875-878 (Fla. Dist. Ct. App. $1^{\text {st }}$ Dist. 1998); Mathews v. Board of Ed. School Dist No. 1, 127 Mich. 530, 531-534 (1901)(exempting children from required vaccinations if parents raise religious objections).

45 Mannis v. State ex. rel. DeWitt School District No. 1, 398 S.W. 2d. 206, 207-208 (Ark. 1965); Com. v. Green, 268 Mass. 585, 585-586 (1929)(holding that vaccinations against small pox could be enforced over parental objection and that non-vaccination of a child could be considered a form of neglect).

46 Mason v. General Brown Cent. School District, 851 F.2d 47, 51-54 (2d Cir. 1988). 
47 See Curry, note 44 supra at 877-879 and In re LePage 18 P.3d 1177, 1180-1181 (Wyo. 2001).

48 National Childhood Vaccine Injury Act 42 U.S.C. §§ 300aa-1 to 300aa-34 (2012).

${ }^{49}$ Elizabeth Breen, A One Shot Deal: The National Childhood Vaccine Act, 41 WM. \& MARY L. ReV. 309, 316-319 (1999).

50 Wilkinson v. Vessey, 295 A.2d 676, 685-687 (R.I. 1978).

51 Lori Andrews, My Body, My Property, 16 Hastings. CT. Rep. 28, 31 (1986).

52 Mason v. Ellsworth, 474 P.2d 909, 918-919 (Wash. App. 3d Dist. 1970).

53 Oonah Corrigan, Empty Ethics: The Problem with Informed Consent, 25 Sociol. HeALTH ILLN. 768,788 (2003).

${ }^{54}$ Franklin v. U.S., 992 F.2d 1492, 1496 (10th Cir. Ct. App. 1993).

55 Michael Myers, Informed Consent in Medical Malpractice, 55 CALIF. L. ReV. 1396, 1399-1403 (1967).

${ }^{56}$ Laurent Frantz, Annotation, Modern Status of Views as to General Measure of Physician's Duty to Inform Patient of Risks of Proposed Treatment, 88 ALR 3d. 1008, 1012-1013 (1978).

57 Alan Meisel, The "Exceptions" to the Informed Consent Doctrine: Striking a Balance Between Competing Values in Medical Decision Making, 1979 WIS. L. ReV. 413, 419-488 (1979).

58 Joseph Goldstein, For Harold Lasswell: Some Reflections on Human Dignity, Entrapment, Informed Consent, and the Plea Bargain, 84 YALE L.J. 683, 690-698 (1975).

59 See Meisel, note 57 supra at 432-433.

${ }^{60}$ Bang v. Charles T. Miller Hospital, 88 N.W.2d, 186, 189-190 (Minn. 1958).

${ }^{61}$ Armand Arabian, Informed Consent: From the Ambivalence of Arto to the Thunder of Thor, 10 ISSUES L. \& MED. 261, 284-294 (1994).

62 L.C. DiStasi, Annotation, Power of Courts or Other Public Agencies, in the Absence of Statutory Authority, to order Compulsory Medical Care for Adult, 9 A.L.R. 3d, 1391, 1393. (1966).

63 Arthur Caplan, Denying Autonomy in Order to Create It: The Paradox of Forcing Treatment Upon Addicts, 103 Addiction 1919, 1919-1920 (2008).

64 Kathy Swedlow, Forced Medication of Legally Incompetent Prisoners: A Primer, 30 Hum. RTS. 3, 3-5 (2003). 
65 Peter Wood, The Right to Refuse Medical Treatment: The Courts' Disparate Treatment of Incarcerated Patients, 112 PenN. St. L. ReV. 1167, 1167-1173 (2008).

${ }^{66}$ Norman Canto, A Patient's Decision to Decline Life Saving Medical Treatment: Bodily Integrity Versus the Preservation of Life, 26 RUtGeRs L. ReV. 228, 230-254 (1972).

67 U.S. CONST. AMEND. XIV, § 1.

68 Cruzan v. Director of Missouri Department of Health, 497 U.S. 261, 286-287 (1990).

69 Bryan Hilliard, The U.S. Supreme Court and Medical Ethics, 184-185 (2004).

${ }^{70}$ Elizabeth Malloy, Beyond Misguided Paternalism: Resuscitating the Right to Refuse Medical Treatment, 33 WAKE FOREST L. REV. 1035, 1056-1091 (1998).

${ }^{71}$ Robert Byrn, Compulsory Lifesaving Treatment for the Competent Adult, 44 FoRdHAM L. REV. 1, 29-33 (1975).

72 L.C. DiStasi, Annotation, Power of Courts or Other Public Agencies, in the Absence of Statutory Authority, to Order Compulsory Medical Care for Adult, 9 A.L.R. 3d, 1391, 1393 (1996).

73 Id.

${ }^{74}$ Application of the President and Directors of Georgetown College, 331 F.2d 1000, 1006 (D.C. 1965).

${ }^{75}$ Id. at $1007-1010$.

76 See DiStasi, note 72 supra.

77 Raleigh Fitkn-Paul Memorial Hospital v. Anderson, 201 A.2d 537, 537-538 (1964).

${ }^{78}$ Id. at $423-424$.

79 M. Gaggenheim, WHAT'S WRONG WitH CHILDREN'S RightS, 20-21 (2005).

${ }^{80}$ Bellotti v. Baird, 443 U.S. 622, 633-635 (1979).

${ }^{81} \mathrm{H}$. Brighouse \& Adam Swift, "Parents' Rights and the Value of the Family", Ethics 117, no. 1 (2006): 80-81.

82 Parham v. J.R., 442 U.S. 584, 602-605 (1979).

${ }^{83}$ New Mark v. Williams, 588 A.2d 1108, 1120-1121 (Del. 1991).

${ }^{84}$ Mueller v. Auker, 576 F.3d 979, 991-1007 (9th Cir. 2009).

85 Prince v. Massachusetts, 321 U.S. 158, 170 (1944). 
86 James Dwyer, Who Decides?, 9 The NATURE OF CHILDREN's Well-Being: IndiCATORS AND ReSEARCH, $157,168-169$ (2015).

87 Jay Zitter, Power of Court of Other Public Agency to Order Medical Treatment Over Parental Religious Objections for Child Whose Life is Not Immediately Endangered, 21 ALR 5th 248, 256257 (1994).

${ }^{88}$ Barbara Bennett Woodhouse, From Property to Personhood: A Child-Centered Perspective On Parents' Rights, 5 Geo. J. ON Fighting PoverTy 313, 319-320 (1998).

89 Mitchell v. Davis, 205 S.W. 2d 812, 813-815 (Ct. Civ. App. Tex. 1947).

${ }^{90} I d$.

${ }^{91}$ Susan Dudley, Note, Medical Treatment for Asian Children - Does Mother Know Best?, 92 Geo. L.J. $1287,1290-1296$ (2003).

92 Lucinda E. Jesson \& Stacey A. Tovino, ComplementARy And Alternative Medicine AND the LaW, 268280 (2010).

93 Kathi J Kemper et al., The Use of Complementary Alternative Medicine in Pediatrics, 122 Pediatrics 1374, 1379 (2008).

94 Scott Becker et Al., Health Care law: A Practical Guide, §19.06[4][c][ii] (2d ed. 1998).

95 Bonner v. Moran, 126 F.2d 121, 122-123 (D.C. Cir. 1941).

${ }^{96}$ American Academy of Pediatrics v. Lungren, 940 P.2d 797, 801 (Cal. 1997).

97 See Becker, note 94 supra at §19.06[2]-§19.06[3][b].

98 Id. at $\S 19.06[3][b]$.

${ }^{99}$ Carol F. Munson, Toward a Standard of Informed Consent by the Adolescent in Medical Treatment Decisions, 85 Dick. L. REV. 431, 436 (1980).

100 Smith v. Seiby, 431 P.2d 719, 723-724 (Wash. 1967).

101 Lois A. Weithorn and Susan B. Campbell, The Competency of Children and Adolescents to Make Informed Treatment Decisions, 53 CHILD DeVELOPMENT 1589, 1596 (1982).

102 Anthony Austin, Note, Medical Decisions and Children: How Much Voice Should Children Have in Their Medical Care?, 49 ARIZ. L. ReVIEW 143, 149-160 (2007).

103 In Re Cassandra C., 112 A.3d 158, 167-173 (Conn. 2015). 
104 Id. at $160-161$.

105 Id. at $163-165$.

106 Id. at 164.

107 Id. at 166.

$108 \mathrm{Id}$.

${ }^{109}$ Id. at 165.

110 Id. at 166.

${ }^{111}$ Id. at $167-168$.

112 Id. at 169.

113 Id. at $168-169$.

${ }^{114}$ Id. at $169-170$

${ }^{115}$ Id. at $172-173$.

116 Virginia Aldige Hiday et al., Patient Perceptions of Coercion in Mental Hospital Admission, 20 INT'L J.L. \& PSYCHIATRY 227, 227-228 (1997).

117 Udo Schuklevk, Protecting the Vulnerable: Testing Times for Clinical Research Ethics, 51 Soc. SCI. \& MED. 969, 970-977 (2000).

118 Protection of Human Subjects 45 C.F.R. $\S \$ 46.101-46.505$ (2015).

119 Laurence O. Gostin, Biomedical Research Involving Prisoners Ethical Value and Legal

Regulation, 297 J. AM. Med. Ass'N. 737 (2007).

${ }^{120}$ Id. at $737-738$

${ }^{121}$ Richard Delgado \& Helen Leskovac, Informed Consent in Human Experimentation: Bridging the Gap Between Ethical Thought and Current Practice, 34 UCLA L. ReV. 67, 67-69 (1986).

122 David J. Moser et al., Coercion and Informed Consent in Research Involving Prisoners, 45 Comprehensive Psychiatry 1, 2-3 (2004).

${ }^{123}$ Additional Protections Pertaining to Biomedical and Behavioral Research Involving Prisoners as Subjects 45 C.F.R. §§ 46.301-46.306 (2015).

${ }^{124}$ See Moser, note 122 supra at 6-8.

125 See Gostin, note 119 supra at 738-739. 
${ }^{126}$ Anna C. Mastroianni \& Jeffery P. Kahn, Risk and Responsibility: Ethics, Grimes v. Kennedy Krieger, and Public Health Research Involving Children, 92 AM. J. PuBLIC HEALTH 1073, 1075-1076 (2002).

127 See Becker, note 94 supra at $\S 19.06[6]$.

128 Hart v. Brown, 289 A.2d 386, 390-391 (Con. Super. Ct. 1972).

129 See Bonner, note 95 supra.

130 Additional Protections for Children Involved as Subjects in Research 45 C.F.R. §§ 46.40146.409 (2015).

131 William L. Freeman, Research and Healthy Children: Greater than Minimal Risk, 16 ETHICS \& HumAN RESEARCH 1, 4 (1994).

${ }^{132}$ Id. at 2.

133 Grimes v. Kennedy Krieger Inst. Inc., 782 A2d 807, 858 (Md. 2001).

${ }^{134}$ Id. at 852-859.

135 Id. at 858.

136 Hironimus v. Nebus, 151 So.3d 1262 (Table)(Fla. 4th Dist. Ct. App. 2014).

137 Associated Press, Mother Agrees to Son's Circumcision in Exchange for Release from Florida Jail, GuARDian, May 22, 2015, http://www.theguardian.com/us-news/2015/may/22/florida-momagrees-sons-circumcision-jail.

138 Defendant Dennis Nebus' Motion to Dismiss Plaintiff's Complaint and Incorporated Memorandum of Law at 3, Hironimus v. Nebus (2015)(No. 9:15-CV-804080-MARRA). 139 Civil Rights Complaint Under Title 42 United States Code Sections 1983 and 1985 at 2, Hironimus v. Nebus (2015)(No. 9:15-CV-804080-XXXX).

140 See note 138 supra at 5-6.

${ }^{141}$ See note 139 supra at 4.

142 Id. at 4-7.

${ }^{143}$ See Associated Press, note 137 supra.

${ }^{144} I d$.

${ }^{145} I d$. 
146 Associated Press, Circumcision for Florida 4-year-old Divides Parents, Spurs Lengthy Legal

Battle and Draws Protests, N.Y. DAILY NEWS, January 20, 2015, http://www.nydailynews.com/news/national/circumcision-fla-4-year-old-divides-parents-article-

1.2084781. 